\title{
The Joint Effects of Precipitation Gradient and Afforestation on Soil Moisture across the Loess Plateau of China
}

\author{
Qindi Zhang ${ }^{1,2,3} \mathbb{D}^{-}$, Wei Wei ${ }^{1,4, * \mathbb{D}}$, Liding Chen ${ }^{1,4}$ and Lei Yang ${ }^{1,4}$ \\ 1 State Key Laboratory of Urban and Regional Ecology, Research Center for Eco-Environmental Sciences, \\ Chinese Academy of Sciences, Beijing 100085, China; nyzqd@126.com (Q.Z.); liding@rcees.ac.cn (L.C.); \\ leiyang@rcees.ac.cn (L.Y.) \\ 2 College of Life Sciences, Shanxi Normal University, Linfen 041000, China \\ 3 Center for Ecosystem Science and Society, Northern Arizona University, Flagstaff, AZ 86011, USA \\ 4 University of Chinese Academy of Sciences, Beijing 100049, China \\ * Correspondence: weiwei@rcees.ac.cn; Tel.: +86-10-6291-8673
}

Received: 4 February 2019; Accepted: 20 March 2019; Published: 22 March 2019

\begin{abstract}
Understanding the dependence of soil moisture changes following afforestation on the precipitation gradient and afforested vegetation types is crucial for improving ongoing afforestation projects, and to guide future restoration strategies in water-limited regions. For this study, we characterized afforestation-induced changes in soil moisture at depths of 0-3.0 $\mathrm{m}$ across a precipitation gradient in the semi-arid Loess Plateau of China. A paired experiment was conducted across 15 sites, where native grasslands served as the baseline hydrology. The results showed that korshinsk peashrub (Caragana korshinskii Kom.), sea buckthorn (Hippophae rhamnoides L.), and black locust (Robinia pseudoacacia L.) afforestation caused an overall strong decline in soil moisture content at depths of below $2.2 \mathrm{~m}$. The degree of soil moisture decline at the regional scale did not vary between different afforested vegetation types but was contingent on precipitation. With decreasing precipitation gradients, afforestation increased the cost of deep soil moisture. Precipitation restrictions began to appear at mean annual precipitation $(\mathrm{MAP})=520 \mathrm{~mm}$, and were intensified at MAP $=380 \mathrm{~mm}$, which could be employed to divide the Loess Plateau into different ecological regions. Because of this, different strategies should be assigned in future restoration practices to these ecological regions to align with localized precipitation conditions. It will likely be prudent to encourage afforestation in areas with MAP of more than $520 \mathrm{~mm}$, while advocating alternative grassland restoration in areas with MAP of less than $380 \mathrm{~mm}$.
\end{abstract}

Keywords: afforestation; soil moisture; precipitation gradient; restoration strategy; Loess Plateau

\section{Introduction}

Afforestation (human-aided tree and shrub plantations) produces various ecological benefits such as carbon sequestration, climate change mitigation, soil erosion control, and sediment load decline [1-4]; thus, it is considered to be an effective ecosystem restoration strategy [5]. Accordingly, afforestation has been implemented extensively around the world over the last century [6]. However, the introduced plantations with high-density planting and evapotranspiration in water-restricted ecosystems may consume more water from soil compared with the original vegetation types, aggravating local water scarcity, and potentially leading to soil desiccation [7]. Decline in soil moisture may reduce gross primary production through ecosystem water stress, induce vegetation mortality, and further exacerbate climate extremes due to land-atmosphere feedbacks, particularly in arid and semi-arid 
areas [8,9]. Therefore, the characterization of influences on soil moisture via afforestation is critical to ecosystem sustainability in water-limited regions.

The impacts of afforestation on soil moisture have been widely reported in various areas [10-13]. Most studies have assessed the effects of afforestation by comparing plantations with original vegetation types (e.g., croplands or grasslands) at the watershed scale [14]. However, aside from negative effects, some plantations exhibited negligible [15] or positive effects [16] on soil moisture. These inconsistent conclusions restricted extrapolations to other regions. Recent studies revealed that the influences of afforestation on soil moisture also differed with variable ranges in precipitation $[6,17]$. For instance, trees planted in sufficient precipitation regions may improve water retention and infiltration capacities, thereby increasing soil moisture. This implies that one potential limiting factor is the precipitation gradient. Furthermore, the soil-vegetation-atmosphere system indicated that the influences of afforestation on soil moisture also depended on afforested vegetation types [17,18]. Given that dominant vegetation types inevitably vary greatly along extensive precipitation gradients, there remains considerable uncertainty at the regional scale. Thus, it is critical to quantify the influences of afforestation on soil moisture with different afforested vegetation types along a precipitation gradient in arid and semi-arid areas.

The Loess Plateau, situated in the upper and middle reaches of the Yellow River in Northwestern China, is considered as one of the most severely eroded areas in the world [19]. To control soil erosion, a series of large-scale afforestation projects have been implemented to reconvert arable land to forestry and grass, such as the Grain-for-Green Project [20]. Under these projects, afforested areas increased from $14.8 \%$ to $21.7 \%$ by 2010 , and introduced plantations became the dominant vegetation [8]. However, large-scale afforestation with introduced vegetation such as korshinsk peashrub (Caragana korshinskii, CK), sea buckthorn (Hippophae rhamnoides, HR), and black locust (Robinia pseudoacacia, RP), required excessive amounts of soil water [21-23], which gradually led to the formation of dry soil layers widely across the Loess Plateau [7]. These dry soil layers have become an ominous indicator of the soil desiccation phenomenon and ecosystem vulnerability in the Loess Plateau [8]. In addition, these plantations created potentially conflicting demands for water between ecosystems and humans [24]. In this region, ecosystems and human activities both depend on precipitation. The afforestation-induced lack of water has seriously hampered local people's wellbeing [8]. As such, the matching of species to localized site conditions is extremely critical to promote sustainable management of afforested ecosystems and safeguard socioeconomic water demands for these water-limited areas of the world [25].

The Loess Plateau of China provides an ideal ecosystem for examining the hydrological consequences of afforestation with different vegetation types along a precipitation gradient. Due to its great geographical magnitude, the average annual precipitation varies from $123 \mathrm{~mm}$ in the northwest to $798 \mathrm{~mm}$ in the southeast, as measured 1981-2010. Three commonly introduced plantations (C. korshinskii, H. rhamnoides, and R. pseudoacacia) sequentially dominate from the northwest to southeast. In this study, pairwise samples from 15 afforested/control sites were used to quantify the influences of large-scale afforestation on soil moisture using the three aforementioned plantations across the central Loess Plateau, China. It was hypothesized that afforestation produced changes in the soil moisture content, where the precipitation gradient and afforested vegetation types jointly determined the degree of soil moisture changes at the regional scale. Thus, the objectives of this study were to: (i) Characterize the afforestation-induced changes in vertical soil moisture with each vegetation type; (ii) detect the effects of the precipitation gradient and afforested vegetation types on the degree of soil moisture changes at different soil layers; and (iii) develop recommendations to improve future restoration practices in the Loess Plateau and other water-limited regions. 


\section{Materials and Methods}

\subsection{Study Area}

A northwest-southeast transect was selected from across the hinterland of the Loess Plateau (35.66-37.32 $\mathrm{N}$ and $106.18-111.92^{\circ} \mathrm{E}$ ). The transect is a typical loess hilly region, with average annual precipitation, from $250 \mathrm{~mm}$ in the northwest, to $550 \mathrm{~mm}$ in the southeast. Due to its broad precipitation gradient, this region encompasses three vegetation zones from northwest to southeast (typical steppe zone, forest-steppe zone, and forest zone) [26]. The sampling sites were selected based on the precipitation gradient (Figure 1), which covered all of the primary regional climate conditions and afforested vegetation types. The broadleaved plantations in the area are sequentially dominated by C. korshinskii, H. rhamnoides, and R. pseudoacacia, spanning from the northwest to southeast. These trees were widely planted around the Loess Plateau due to their robust drought resistance, high survival rate, nitrogen fixation, and fast growth rate $[6,12,23]$.

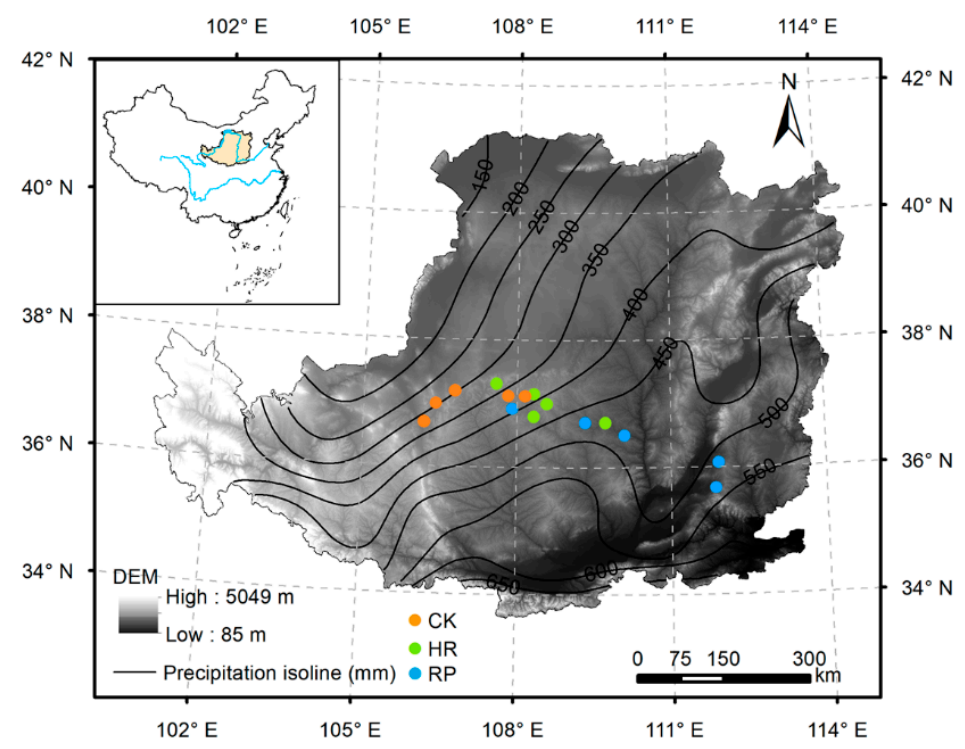

Figure 1. Location of sampling sites along the precipitation gradient in the Loess Plateau. Mean annual precipitation was derived from a precipitation map based on 273 meteorological stations across the entire Loess Plateau (Climate Database, National Meteorological Information).

\subsection{Experimental Design and Soil Sampling}

A paired experiment was conducted across the study region during the growing season (July 2016). Each site contained a plantation plot and a native grassland plot. The plantation was obtained from the three aforementioned tree species, and the stand ages, determined via the tree-ring method, were between 18-25 years. The native grasslands were dominated by bunge needlegrass (Stipa spp.) and represented the initial control hydrology prior to afforestation. Five sites with each vegetation type (15 sites in total), were surveyed (Figure 1). For each plantation plot, a vegetation investigation was conducted within four $10 \mathrm{~m} \times 10 \mathrm{~m}$ subplots. The plant height $(\mathrm{m})$, canopy cover, and stand density (plants/ha) within each subplot were quantified, respectively. At the R. pseudoacacia sites, the diameter at breast height $(\mathrm{DBH}, \mathrm{cm})$ were also recorded. The vegetation characteristics for each type of plantation are shown in Table 1.

To optimize data representativeness, each paired afforested/control plot had similar topographic characteristics: south-facing, upper slope, and less than $3 \mathrm{~km}$ apart. The slope gradients and aspects (clockwise from north) were determined for each plot using a compass, and both were recorded in degrees. At each site, soil samples were collected from depths of $0-0.2 \mathrm{~m}$. The soil texture was determined using a laser diffraction instrument (Mastersizer 2000, Malvern Instruments Ltd., 
Malvern, UK). Subsequently, three proportions of clay $(<0.002 \mathrm{~mm})$, silt $(0.002-0.02 \mathrm{~mm})$, and sand $(>0.02 \mathrm{~mm})$ contents were calculated. The soil organic matter $(\mathrm{SOM})$ content was analyzed by the dichromate oxidation method. Undisturbed soil cores were collected to measure soil bulk density using a stainless-steel cutting ring (volume $100 \mathrm{~mm}^{3}$ ). The topographic and soil properties for each type of plantation are shown in Table 2 .

Table 1. Vegetation characteristics for each type of plantation.

\begin{tabular}{lccccc}
\hline \multirow{2}{*}{$\begin{array}{c}\text { Vegetation } \\
\text { Type }\end{array}$} & Plantation Age & Canopy Cover & Height & Stand Density & DBH \\
\cline { 2 - 6 } & $\mathbf{( y e a r )}$ & $\mathbf{( \% )}$ & $\mathbf{( m )}$ & (plants/ha) & $\mathbf{( c m )}$ \\
\hline Korshinsk peashrub (C. korshinskii) & 22 & 0.50 & 1.9 & 1580 & NA \\
Sea buckthorn (H. rhamnoides) & 24 & 0.74 & 1.8 & 2936 & NA \\
Black locust (R. pseudoacacia) & 20 & 0.83 & 9.8 & 1371 & 9.7 \\
\hline
\end{tabular}

Note: DBH represents the diameter at breast height.

Table 2. Topographic and soil properties for each type of plantation.

\begin{tabular}{|c|c|c|c|c|c|c|c|c|}
\hline \multirow{3}{*}{$\begin{array}{c}\text { Vegetation } \\
\text { Type }\end{array}$} & \multicolumn{3}{|c|}{ Topographic Properties } & \multicolumn{5}{|c|}{ Soil Properties } \\
\hline & SG & SA & SP & BD & Clay & Silt & Sand & SOM \\
\hline & $\left({ }^{\circ}\right)$ & $\left({ }^{\circ}\right)$ & & $\left(\mathrm{g} / \mathrm{cm}^{3}\right)$ & $(\%)$ & $(\%)$ & $(\%)$ & $(\mathrm{g} / \mathrm{kg})$ \\
\hline Korshinsk peashrub (C. korshinskii) & 7 & 182 & Upper & 1.19 & 3.2 & 29.1 & 67.7 & 4.4 \\
\hline Sea buckthorn (H. rhamnoides) & 4 & 186 & Upper & 1.15 & 4.2 & 33.6 & 62.2 & 5.9 \\
\hline Black locust (R. pseudoacacia) & 10 & 198 & Upper & 1.13 & 5.1 & 47.8 & 47.1 & 6.5 \\
\hline
\end{tabular}

Note: SG represents slope gradient; SA represents slope aspect; SP represents slope position; BD represents bulk density; SOM represents soil organic matter.

The soil moisture content (SMC) at depths of 0-3.0 m was measured by the gravimetric method (unit: $\mathrm{g} / \mathrm{g}$ ). To ensure the comparability in soil moisture content between the different sites, no rainfall events occurred at least a week prior to soil sampling. Soil samples were extracted using a $(\varnothing 5 \mathrm{~cm})$ drill at $0.2 \mathrm{~m}$ intervals, making 15 soil samples for each plot, for a total of 450 soil samples. These soil samples were immediately sealed in airtight aluminum cylinders and weighed for the first time, and then transported to the laboratory for $24 \mathrm{~h}$ drying at $105^{\circ} \mathrm{C}$ using an oven-dry method.

\subsection{Calculation of Degree of Soil Moisture Changes following Afforestation}

The degree of soil moisture changes following afforestation in the paired experiment was calculated using the log response ratio (LNRR) at each site [27]:

$$
\mathrm{LNRR}=\ln \left(\mathrm{SMC}_{\mathrm{P}} / \mathrm{SMC}_{\mathrm{NG}}\right)
$$

where $\mathrm{SMC}_{\mathrm{P}}$ is soil moisture in a plantation plot, and $\mathrm{SMC}_{\mathrm{NG}}$ is soil moisture in the control grassland plot. LNRR $<0$ signifies that afforestation causes a decrease in soil moisture and LNRR $>0$ denotes a positive effect of afforestation on soil moisture.

The depth-averaged LNRR for each experimental site was calculated using Equation (2):

$$
\mathrm{LNRR}_{j}=\frac{1}{i} \sum_{i=1}^{i} L N R R_{i j}
$$

where $i$ is the number of measurement layers at site $j$ and $\operatorname{LNRR}_{i j}$ is the $\log$ response ratio in layer $i$ at site $j$. 


\subsection{Statistical Analysis}

First, paired-sample $T$-tests were applied to detect the differences in the vertical soil moisture content for each afforested vegetation type, and in the control grassland. Second, redundancy analyses were conducted to isolate the degree of soil moisture changes following afforestation due to the precipitation gradient and afforested vegetation types. The intensity of soil moisture changes following afforestation was calculated using LNRR (Equation (1), and the vegetation types were represented by the absence or presence of dummy variables. The significance of the explanatory variables was tested using Monte Carlo simulations. Third, linear piecewise quantile regression was performed to explore the response of LNRR to the mean annual precipitation (MAP) as the potential constraint [28].

\section{Results}

\subsection{Comparison of Soil Moisture between each Afforested Vegetation and Control Grassland}

Figure 2 reveals the averaged soil moisture content of the afforested vs. control sites for each plantation type. The soil moisture content in C. korshinskii, H. rhamnoides, and R. pseudoacacia plantations was lower at the measured soil depths in contrast to the grassland control. Specifically, a significant difference of the soil moisture at depths of below $1.4 \mathrm{~m}$ was found between $C$. korshinskii plantations and native grasslands (Figure 2a). Both H. rhamnoides and R. pseudoacacia plantations had a significantly lower value of soil moisture content at depths of below $2.2 \mathrm{~m}$ (Figure $2 \mathrm{~b}, \mathrm{c}$ ). Overall, this result indicated that three plantation types had a significant impact on deep soil moisture. Further, the $1.4 \mathrm{~m}$ and $2.2 \mathrm{~m}$ soil depth were the boundaries for distinguishing this influence on the soil moisture profile. Accordingly, we divided the soil profile into three layers for the subsequent analysis: Upper layer (0-1.4 m), middle layer (1.4-2.2 m), and deep layer (2.2-3.0 m).
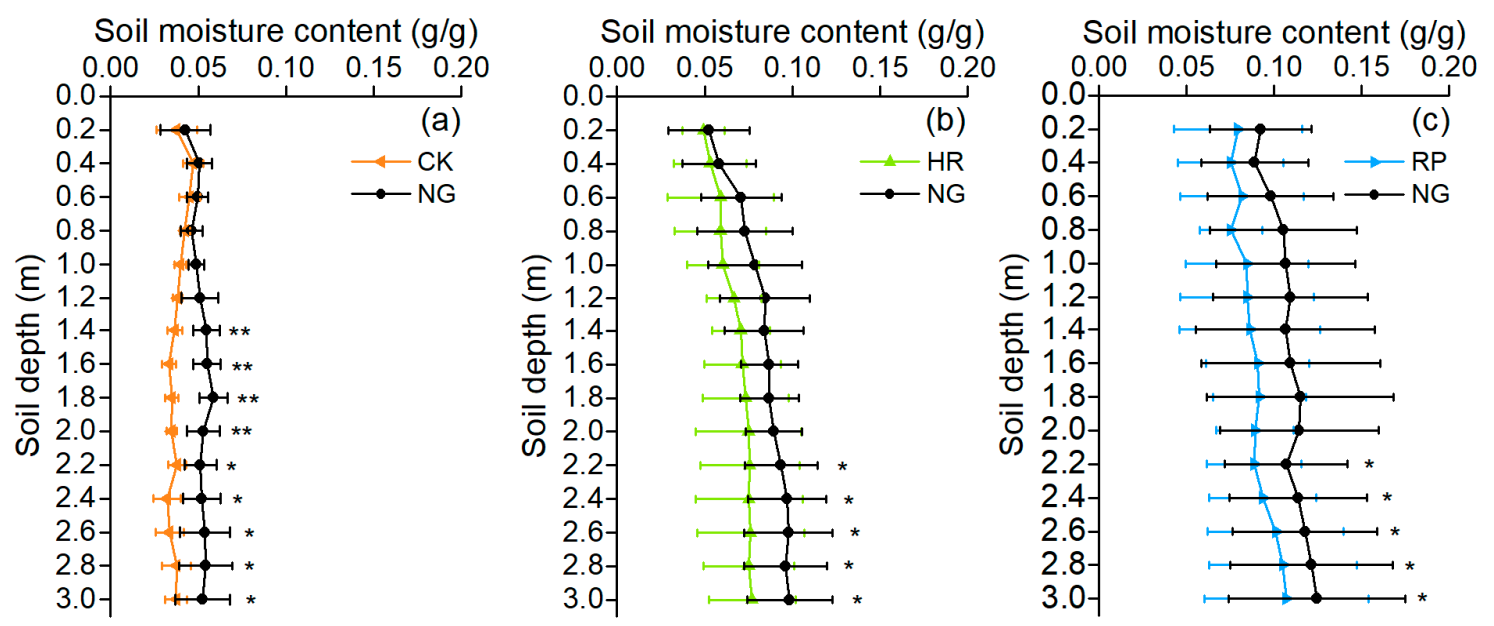

Figure 2. Soil moisture profiles for each vegetation type and the native grassland (NG) control. (a) korshinsk peashrub (C. korshinskii, CK); (b) sea buckthorn (H. rhamnoides, HR); (c) black locust (R. pseudoacacia, RP). The bars denote the standard deviation of the mean $(n=5) .{ }^{*}, p<0.05 ;{ }^{* *}, p<0.01$.

\subsection{Contribution of Precipitation and Afforested Vegetation Types to Degree of Soil Moisture Change}

The proportion of the precipitation gradient and afforested vegetation types that contributed to the degree of soil moisture changes following afforestation (LNRR) is depicted in Figure 3. Precipitation was the more critical driver of the degree of soil moisture changes, over the vegetation types, although their importance varied between soil layers. Both precipitation and vegetation types did not significantly affect the LNRR in the upper layer (0-1.4 m). Furthermore, the vegetation types did not reveal significant effects in the middle (1.4-2.2 m) or deep (2.2-3.0 m) layers. In contrast, precipitation had significant effects on the LNRR at depths of below $1.4 \mathrm{~m}$, and these effects revealed an increasing 
trend with soil layers. In short, precipitation was confirmed as the dominant factor that influenced the degree of soil moisture changes, with a major effect at depths of below $1.4 \mathrm{~m}$.

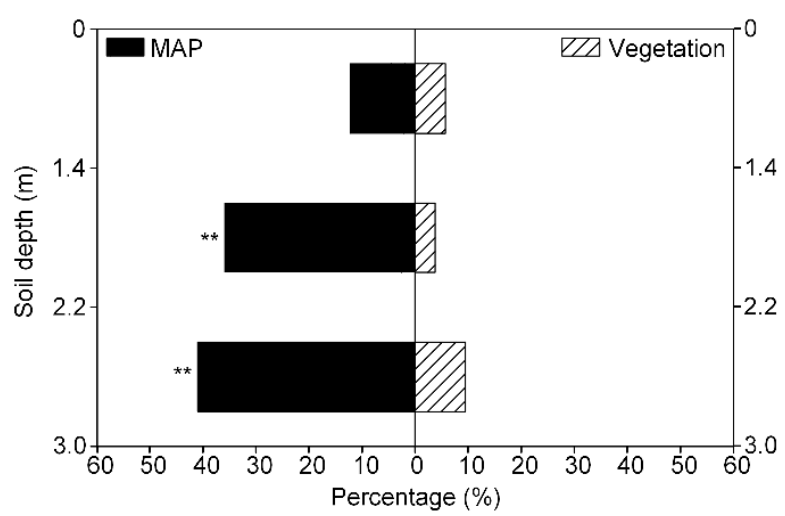

Figure 3. The proportion of mean annual precipitation (MAP) and vegetation types contributing to the variance of the log response ratio (LNRR) at different soil depths, based on the redundancy analysis (RDA). ${ }^{* *}, p<0.01$.

\subsection{Degree of Soil Moisture Changes following Afforestation along Precipitation Gradient}

The overall response processes of LNRR under the measured plantations were examined across the precipitation gradient (Figure 4). It should be noted that depth-averaged LNRR was always less than zero, indicating the degree of soil moisture decline relative to the baseline hydrology. The range of LNRR in the upper layer $(0-1.4 \mathrm{~m})$ varied greatly with the precipitation gradient; however, no obvious LNRR trend was detected (Figure 4a). Rather, LNRR below $1.4 \mathrm{~m}$ exhibited a decreasing trend with decreasing precipitation gradients. Hereinto, the trend of LNRR in the middle layer (1.4-2.2 m) remained stable, and then dropped off rapidly when MAP $<380 \mathrm{~mm}$ (Figure $4 \mathrm{~b}$ ). The LNRR in the deep layer $(2.2-3.0 \mathrm{~m})$ remained stable and then decreased slightly with decreasing precipitation gradients. The turning point of LNRR in the deep layer was at MAP $=520 \mathrm{~mm}$ (Figure 4c).
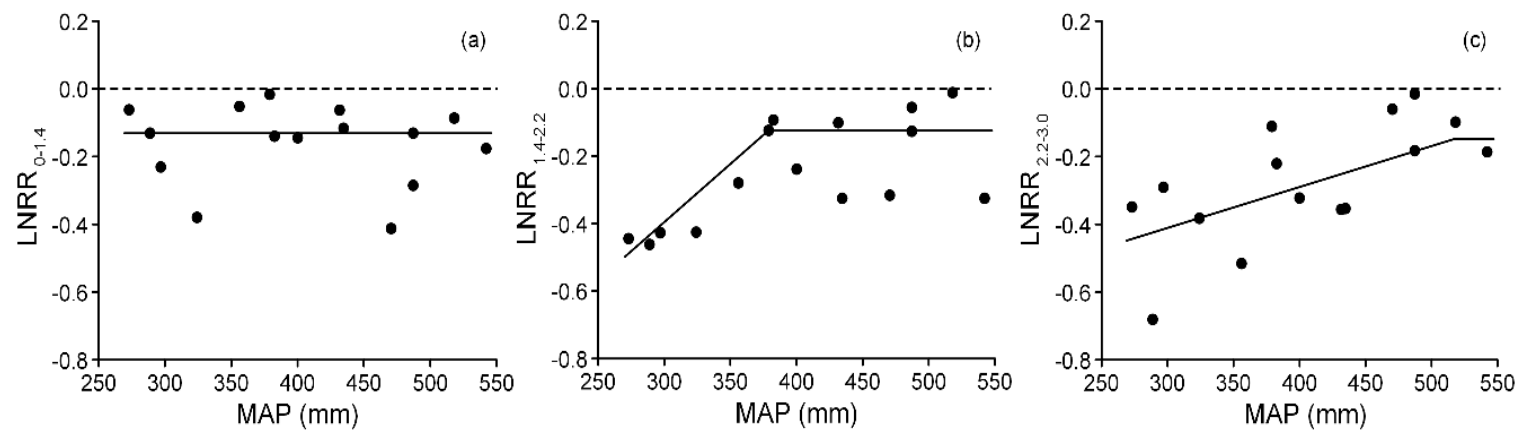

Figure 4. Changes in LNRR with the mean annual precipitation (MAP) gradient. (a) LNRR at 0-1.4 m; (b) LNRR at 1.4-2.2 m; (c) LNRR at 2.2-3.0 m.

\section{Discussion}

\subsection{Negative Effects of Afforestation on Vertical Soil Moisture}

Both C. korshinskii and H. rhamnoides are native shrubs of China, while R. pseudoacacia is an exotic broadleaved tree from Southeastern North America. Due to their economic benefits and ecological value, they have gradually become dominant species that are widely planted across the Loess Plateau $[29,30]$. However, the hydrological impacts of large-scale afforestation remain highly controversial [19]. This study showed that C. korshinskii, H. rhamnoides, and R. pseudoacacia afforestation induced decreased soil moisture in the deep soil layer (2.2-3.0 m) (Figure 2), which was consistent 
with previous studies at watershed scales [31-33]. The rationale for this might be that the three trees investigated in this study always had deep root systems, and therefore consumed large quantities of deep soil moisture due to their high evapotranspiration and planting density (Table 1). For this study, the soil moisture in native grassland served as the baseline hydrology prior to afforestation. Previous studies found that the root systems of native grassland were primarily distributed at depths of 0-0.5 m [34]. Compared with native grassland, these tree species distribute most root systems at depths of 0-1.0 m [31], while they often extended their roots into deep soil layers. For example, the roots of C. korshinskii reached depths of $6.4 \mathrm{~m}$ [35], with H. rhamnoides to $8.0 \mathrm{~m} \mathrm{[36]} \mathrm{and} \mathrm{R.} \mathrm{pseudoacacia} \mathrm{to} \mathrm{more}$ than $7.0 \mathrm{~m}$ [37]. Precipitation is the only source of soil moisture in the Loess Plateau on account of deep groundwater levels [6]. However, rainfall infiltration does not always compensate for soil moisture consumption during the growing season [38]. Therefore, it was concluded that afforestation markedly disrupted the balance of deep soil moisture due to developed deep root systems, thereby driving a lack of soil moisture in the deep soil layer across the Loess Plateau.

On the other hand, the moisture in the upper soil layer $(0-1.4 \mathrm{~m})$ for the three plantations was not obviously lower than that in the control grassland (Figure 2), which was consistent with recent studies on the spatial variations of soil moisture under different land uses in the Loess Plateau [18]. Moisture in the upper soil layer might be more susceptible to additional hydro-geographical factors in contrast to the deep soil layer, such as rain throughfall, canopy interception, and soil evaporation [39]. Compared with native grassland, plantations typically have obvious canopy structures, such as canopy cover, as well as increased plant height and density (Table 1). However, these canopy structures could lead to opposite effects for moisture in the upper soil layer. For example, under identical precipitation intensity conditions, the amount of precipitation throughfall in plantations is less than the quantity in grasslands due to canopy interception, which results in lower soil moisture in plantations [40]. On the contrary, soil evaporation in plantations is lower than that in grassland due to the higher canopy cover and lower soil temperature [41]. Thus, it was not surprising in this study that moisture in the upper soil layer in some plots was slightly higher than that in the control plots. Similar results were also reported in Northeastern China [17]. Finally, the herbaceous layer of plantations obviously does not intensify moisture depletion in the upper soil layer, which has been confirmed by understory removal experiments in the Loess Plateau [42]. This is because plantations can greatly decrease herbaceous layer growth and diversity by altering the availability of light $[43,44]$. These opposing effects contribute to inconspicuous differences in the upper layer soil moisture between plantations and the grassland control. Based on the above discussion, it is reasonable that afforestation did not lead to significant impacts on the moisture in the upper soil layer across the Loess Plateau.

\subsection{Controls of Afforested Vegetation Types and Precipitation on Degree of Soil Moisture Decline following Afforestation at Regional Scale}

The results of redundancy analyses indicated that afforested vegetation types had a weak influence on the degree of soil moisture decline following afforestation (Figure 3). Comparisons of soil moisture under different land uses has been well investigated $[7,18,45]$. However, such species-dependent impacts on the degree of soil moisture alterations following afforestation across a precipitation gradient has rarely been explored previously. In this study, afforestation had significant impacts on deep soil moisture below $1.4 \mathrm{~m}$. However, the degree of soil moisture decline following afforestation did not vary greatly with afforested vegetation types, which was inconsistent with our hypothesis that the precipitation gradient and afforested vegetation types jointly determined the degree of soil moisture changes at the regional scale. This suggested that the tree species (C. korshinskii, H. rhamnoides, and R. pseudoacacia) investigated in this study could decrease the deep soil moisture to the same degree in this region, which was consistent with previous research in a watershed of the Loess Plateau [22]

Compared with vegetation types, precipitation was the primary factor that influenced the degree of soil-moisture decline (Figure 3). We noted that the degree of soil moisture changes in the upper layer was independent of the precipitation gradient. One potential explanation was that soil moisture 
in the upper layer was affected by multiple ecosystem processes in water-limited regions, as noted above, and the precipitation gradient might not exert bottleneck for upper layer soil moisture in plantations. In this case, access to water in the upper soil layer to maintain plantations was not obviously constrained by the precipitation gradient (Figure 4a). Conversely, the precipitation gradient had significant effects on the degree of soil moisture decline below $1.4 \mathrm{~m}$ (Figure 3), suggesting that precipitation restrictions intensified the degree of soil moisture decline following afforestation in the Loess Plateau (Figure 4b,c). This worsening trend of soil moisture decline in dry areas may be explained by low infiltration rates. As mentioned earlier, precipitation is the only source of soil moisture, while the quantity and depth of rainfall infiltration is distinct across a precipitation gradient, which has been reported in previous studies [46]. For example, the average rainfall infiltration depth in the Longtan watershed $(\mathrm{MAP}=386 \mathrm{~mm}$ ) was found to be $1.0 \mathrm{~m}$ in a normal year [47], while this depth in the Changwu watershed $(\mathrm{MAP}=584 \mathrm{~mm}$ ) reached $2.0 \mathrm{~m}$ in a drought year and $3.0 \mathrm{~m}$ in a rainy year [38]. Over a large scale, the precipitation varied greatly in the Loess Plateau. Plantations in dry areas had deep roots, even below the rainfall infiltration depth [18], which excessively depleted deep soil water without sufficient replenishment by rainfall. Furthermore, previous studies revealed that the soil organic matter content and clay content decreased with decreasing precipitation gradients in the Loess Plateau, while the bulk density increased $[48,49]$, which further reduced the infiltration rate [50,51]. Similar changes in soil properties were also captured in this study. For example, the C. korshinskii plantation was primarily distributed over relatively dry areas (mean MAP $=320 \mathrm{~mm}$, Figure 1), with the lowest soil organic matter content and clay content, but the highest bulk density between the three plantations (Table 2). Based on the reasons above, water deficits initiated by afforestation intensified as the precipitation gradient decreased. Therefore, precipitation restrictions significantly influenced the degree of decline in soil moisture following afforestation.

The LNRR trends along the precipitation gradient suggested that afforestation increased the cost of deep soil moisture with decreasing precipitation gradients (Figure 4). These precipitation gradient-induced restriction effects on other ecological processes and functions (e.g., soil organic carbon, total nitrogen) were detected in the Loess Plateau in recent studies $[48,49,52]$. For this study, LNRR in the middle soil layer (1.4-2.2 m) dropped off sharply once the precipitation gradient decreased in regions with MAP < $380 \mathrm{~mm}$, while LNRR in the deep soil layer $(2.2-3.0 \mathrm{~m})$ slightly decreased in regions with MAP $<520 \mathrm{~mm}$. This also suggested that the precipitation restriction on the afforestation-induced decline of soil moisture began to appear in relatively humid areas, and was exacerbated in the relatively dry areas.

\subsection{Implications for Future Restoration Strategies}

With the implementation of large-scale restoration projects in the Loess Plateau, some local soil erosion has been successfully controlled. However, high-density afforestation has excessively reduced soil moisture, leading to the formation of dry soil layers across this region [7]. This has further reduced the vegetative carrying capacity of soil water in the Loess Plateau, and also degraded some vegetation communities [8]. The best proof of this is manifested as "the little old man trees" or "dwarfed trees" in the Loess Plateau [53]. In addition, large-scale vegetation restoration projects have reduced river runoff [25]. This has greatly exacerbated water scarcity required by the residential, agricultural, and industrial sectors, potentially affecting more than 100 million people living in the region [24]. Finally, the trade-off of multiple ecosystem functions following afforestation is not necessarily a zero-sum game [54]. For example, soil moisture decline following afforestation might degenerate a forest ecosystem to a grassland, thus accounting for further reductions in the present land carbon sink [9]. Therefore, the priority of ecological restoration is to find a balanced solution of afforestation and water reduction and ultimately ensure that afforestation is ecologically and socially sustainable for this area. Our study demonstrated that afforestation increased the cost of deep soil moisture as the precipitation gradient decreased. Precipitation restrictions began to appear at MAP $=520 \mathrm{~mm}$, and was aggravated at $\mathrm{MAP}=380 \mathrm{~mm}$. These precipitation restrictions may be employed to divide the Loess Plateau into 
distinct ecological regions. From the practical point of view, future restoration measures should be carefully planned, particularly in the regions with MAP $<380 \mathrm{~mm}$.

Restoration projects often encounter conflicts between variable ecological functions (e.g., carbon sequestration and water resources), which require the cautious deployment of restoration strategies to balance multiple objectives. The differentiation of restoration strategies should be assigned to these ecological regions in terms of localized precipitation conditions, taking the Loess Plateau as an example. On the one hand, afforestation may be feasible in areas where the MAP is higher than $520 \mathrm{~mm}$. The reduction of plant density and increasing species diversity based on prudent tree species selection are critical strategies for this region [21]. Furthermore, new research has shown that planted forests have a less positive effect on carbon sequestration; however, they lead to significant water yield reduction in contrast to natural forests [55]. As such, the exotic trees in use should be replaced with less water-demanding native trees to imitate natural forests. On the other hand, afforestation was banned in areas where the MAP was less than $380 \mathrm{~mm}$. Since grassland restoration is considered as an alternative for vegetation restoration in water-limited regions [56], native grassland is strongly advocated to maximize the benefits of ecosystem multifunctionality. For sustainable ecological restoration and construction, further continuous monitoring research on afforestation impacts is urgently required to support more effective restoration strategies, without endangering the availability of soil water in arid and semi-arid areas.

\section{Conclusions}

This study demonstrated how afforestation reduced soil moisture across vertical and horizontal soil cross sections at a regional scale. The results revealed that $C$. korshinskii, $H$. rhamnoides, and R. pseudoacacia afforestation irrespectively induced soil moisture decline below $2.2 \mathrm{~m}$ across the Loess Plateau. The degree of soil moisture decline did not vary between different afforested vegetation types, but was greatly influenced by the precipitation gradient at the regional scale. With decreasing precipitation gradients, afforestation increased the cost of deep soil moisture. Precipitation restrictions began to appear at MAP $=520 \mathrm{~mm}$, and was aggravated at MAP $=380 \mathrm{~mm}$. These restriction points could be used to divide the Loess Plateau into distinct ecological regions, which should be assigned to the differentiation of restoration strategies. Quantifying the dependence of soil moisture changes following afforestation on both the precipitation gradient and vegetation types will be beneficial for adjusting current afforestation projects toward the optimization of future restoration strategies.

Author Contributions: W.W. designed the study; Q.Z. carried out the experiment, analyzed the data, and wrote the first draft of the manuscript; Q.Z., W.W., L.C., and L.Y. contributed with suggestions and corrections, and approved the final manuscript.

Funding: This research was supported by the National Key Research and Development Program of China (2016YFC0501701), the National Natural Science Foundation of China (41601027, 41390462), the National Advanced Project of the Twelfth Five-year Plan of China (2015BAC01B02) and the Youth Innovation Promotion Association of CAS.

Acknowledgments: The authors thank Zongshan Li and Cong Wang for their generous assistance with the field work.

Conflicts of Interest: The authors declare no conflict of interest.

\section{References}

1. Cerdà, A.; Lucas Borja, M.E.; Úbeda, X.; Martínez-Murillo, J.F.; Keesstra, S. Pinus halepensis M. versus Quercus ilex subsp. Rotundifolia L. runoff and soil erosion at pedon scale under natural rainfall in Eastern Spain three decades after a forest fire. For. Ecol. Manag. 2017, 400, 447-456.

2. Yosef, G.; Walko, R.; Avisar, R.; Tatarinov, F.; Rotenberg, E.; Yakir, D. Large-scale semi-arid afforestation can enhance precipitation and carbon sequestration potential. Sci. Rep. 2018, 8, 996. [CrossRef] [PubMed]

3. Yang, Y.; Li, P.; Ding, J.; Zhao, X.; Ma, W.; Ji, C.; Fang, J. Increased topsoil carbon stock across China's forests. Glob. Chang. Biol. 2014, 20, 2687-2696. [CrossRef] [PubMed] 
4. $\quad$ Deng, L.; Shangguan, Z.-P. Afforestation drives soil carbon and nitrogen changes in China. Land Degrad. Dev. 2017, 28, 151-165. [CrossRef]

5. Zethof, J.H.T.; Cammeraat, E.L.H.; Nadal-Romero, E. The enhancing effect of afforestation over secondary succession on soil quality under semiarid climate conditions. Sci. Total Environ. 2019, 652, 1090-1101. [CrossRef]

6. Jin, T.; Fu, B.; Liu, G.; Wang, Z. Hydrologic feasibility of artificial forestation in the semi-arid Loess Plateau of China. Hydrol. Earth Syst. Sci. 2011, 15, 2519-2530. [CrossRef]

7. Wang, Y.; Shao, M.A.; Zhu, Y.; Liu, Z. Impacts of land use and plant characteristics on dried soil layers in different climatic regions on the Loess Plateau of China. Agric. For. Meteorol. 2011, 151, 437-448. [CrossRef]

8. Fu, B.; Wang, S.; Liu, Y.; Liu, J.; Liang, W.; Miao, C. Hydrogeomorphic ecosystem responses to natural and anthropogenic changes in the Loess Plateau of China. Annu. Rev. Earth Planet. Sci. 2016, 45, 223-243. [CrossRef]

9. Green, J.K.; Seneviratne, S.I.; Berg, A.M.; Findell, K.L.; Hagemann, S.; Lawrence, D.M.; Gentine, P. Large influence of soil moisture on long-term terrestrial carbon uptake. Nature 2019, 565, 476-479. [CrossRef]

10. Querejeta, J.I.; Roldán, A.; Albaladejo, J.; Castillo, V.C. Soil water availability improved by site preparation in a Pinus halepensis afforestation under semiarid climate. For. Ecol. Manag. 2001, 149, 115-128. [CrossRef]

11. Nosetto, M.D.; Jobbágy, E.G.; Paruelo, J.M. Land-use change and water losses: The case of grassland afforestation across a soil textural gradient in central Argentina. Glob. Chang. Biol. 2005, 11, 1101-1117. [CrossRef]

12. Jia, X.; Shao, M.A.; Zhu, Y.; Luo, Y. Soil moisture decline due to afforestation across the Loess Plateau, China. J. Hydrol. 2017, 546, 113-122. [CrossRef]

13. Ferreira, C.S.S.; Walsh, R.P.D.; Shakesby, R.A.; Keizer, J.J.; Soares, D.; González-Pelayo, O.; Coelho, C.O.A.; Ferreira, A.J.D. Differences in overland flow, hydrophobicity and soil moisture dynamics between Mediterranean woodland types in a peri-urban catchment in Portugal. J. Hydrol. 2016, 533, 473-485. [CrossRef]

14. Cao, S.; Chen, L.; Shankman, D.; Wang, C.; Wang, X.; Zhang, H. Excessive reliance on afforestation in China's arid and semi-arid regions: Lessons in ecological restoration. Earth Sci. Rev. 2011, 104, 240-245. [CrossRef]

15. Maestre, F.T.; Bautista, S.; Cortina, J.; Bellot, J. Potential for using facilitation by grasses to establish shrubs on a semiarid degraded steppe. Ecol. Appl. 2001, 11, 1641-1655. [CrossRef]

16. Chen, L.-F.; He, Z.-B.; Zhu, X.; Du, J.; Yang, J.-J.; Li, J. Impacts of afforestation on plant diversity, soil properties, and soil organic carbon storage in a semi-arid grassland of northwestern China. Catena 2016, 147, 300-307. [CrossRef]

17. Yao, Y.; Wang, X.; Zeng, Z.; Liu, Y.; Peng, S.; Zhu, Z.; Piao, S. The effect of afforestation on soil moisture content in Northeastern China. PLoS ONE 2016, 11, e0160776. [CrossRef]

18. Wang, C.; Wang, S.; Fu, B.; Yang, L.; Li, Z. Soil moisture variations with land use along the precipitation gradient in the north-south transect of the Loess Plateau. Land Degrad. Dev. 2016, 28, 926-935. [CrossRef]

19. Lü, Y.; Fu, B.; Feng, X.; Zeng, Y.; Liu, Y.; Chang, R.; Sun, G.; Wu, B. A policy-driven large scale ecological restoration: Quantifying ecosystem services changes in the Loess Plateau of China. PLoS ONE 2012, 7, e31782. [CrossRef] [PubMed]

20. Deng, L.; Shangguan, Z.-P.; Sweeney, S. “Grain for Green” driven land use change and carbon sequestration on the Loess Plateau, China. Sci. Rep. 2014, 4, 7039. [CrossRef]

21. Kou, M.; Garcia-Fayos, P.; Hu, S.; Jiao, J. The effect of Robinia pseudoacacia afforestation on soil and vegetation properties in the Loess Plateau (China): A chronosequence approach. For. Ecol. Manag. 2016, 375, 146-158. [CrossRef]

22. Yang, L.; Wei, W.; Chen, L.D.; Mo, B.R. Response of deep soil moisture to land use and afforestation in the semi-arid Loess Plateau, China. J. Hydrol. 2012, 475, 111-122. [CrossRef]

23. Liu, Y.; Zhao, W.; Wang, L.; Zhang, X.; Daryanto, S.; Fang, X. Spatial variations of soil moisture under Caragana korshinskii Kom. from different precipitation zones: Field based analysis in the Loess Plateau, China. Forests 2016, 7, 31. [CrossRef]

24. Feng, X.; Fu, B.; Piao, S.; Wang, S.; Ciais, P.; Zeng, Z.; Lu, Y.; Zeng, Y.; Li, Y.; Jiang, X.; et al. Revegetation in China's Loess Plateau is approaching sustainable water resource limits. Nat. Clim. Chang. 2016, 6, 1019-1022. [CrossRef] 
25. Wang, S.; Fu, B.; Piao, S.; Lu, Y.; Ciais, P.; Feng, X.; Wang, Y. Reduced sediment transport in the Yellow River due to anthropogenic changes. Nat. Geosci. 2016, 9, 38-41. [CrossRef]

26. Li, G.; Wen, Z.; Guo, K.; Du, S. Simulating the effect of climate change on vegetation zone distribution on the Loess Plateau, Northwest China. Forests 2015, 6, 2092-2108. [CrossRef]

27. Gross, N.; Robson, T.M.; Lavorel, S.; Albert, C.; Le Bagousse-Pinguet, Y.; Guillemin, R. Plant response traits mediate the effects of subalpine grasslands on soil moisture. New Phytol. 2008, 180, 652-662. [CrossRef]

28. Ruppert, J.C.; Holm, A.; Miehe, S.; Muldavin, E.; Snyman, H.A.; Wesche, K.; Linstädter, A. Meta-analysis of ANPP and rain-use efficiency confirms indicative value for degradation and supports non-linear response along precipitation gradients in drylands. J. Veg. Sci. 2012, 23, 1035-1050. [CrossRef]

29. Huang, J.; Li, G.; Li, J.; Zhang, X.; Yan, M.; Du, S. Projecting the range shifts in climatically suitable habitat for Chinese Sea Buckthorn under climate change scenarios. Forests 2017, 9, 9. [CrossRef]

30. Zhao, F.; Wang, J.; Zhang, L.; Ren, C.; Han, X.; Yang, G.; Doughty, R.; Deng, J. Understory plants regulate soil respiration through changes in soil enzyme activity and microbial $\mathrm{C}, \mathrm{N}$, and P stoichiometry following afforestation. Forests 2018, 9, 436. [CrossRef]

31. Yang, L.; Wei, W.; Chen, L.; Chen, W.; Wang, J. Response of temporal variation of soil moisture to vegetation restoration in semi-arid Loess Plateau, China. Catena 2014, 115, 123-133. [CrossRef]

32. Fu, B.J.; Wang, J.; Chen, L.D.; Qiu, Y. The effects of land use on soil moisture variation in the Danangou catchment of the Loess Plateau, China. Catena 2003, 54, 197-213. [CrossRef]

33. Silveira, L.; Gamazo, P.; Alonso, J.; Martínez, L. Effects of afforestation on groundwater recharge and water budgets in the western region of Uruguay. Hydrol. Process. 2016, 30, 3596-3608. [CrossRef]

34. Li, P.; Li, Z.; Hao, M.; Zheng, L. Root distribution characteristics of natural grassland on Loess Plateau. Res. Soil Water Conserv. 2003, 10, 144-145. (In Chinese)

35. Wang, Y.; Shao, M.A.; Shao, H. A preliminary investigation of the dynamic characteristics of dried soil layers on the Loess Plateau of China. J. Hydrol. 2010, 381, 9-17. [CrossRef]

36. Cong, X.; Liang, Y.; Li, D. Root characteristics and soil moisture dynamics of Hippophae rhamnoides in semi-arid region of the Loess Plateau. Bull. Soil Water Conserv. 1990, 10, 98-103. (In Chinese)

37. Wang, Z.; Liu, B.; Liu, G.; Zhang, Y. Soil water depletion depth by planted vegetation on the Loess Plateau. Sci. China Ser. D-Earth Sci. 2009, 52, 835-842. [CrossRef]

38. Chen, H.; Shao, M.; Li, Y. The characteristics of soil water cycle and water balance on steep grassland under natural and simulated rainfall conditions in the Loess Plateau of China. J. Hydrol. 2008, 360, 242-251. [CrossRef]

39. Wang, S.; Fu, B.J.; Gao, G.Y.; Yao, X.L.; Zhou, J. Soil moisture and evapotranspiration of different land cover types in the Loess Plateau, China. Hydrol. Earth Syst. Sci. 2012, 16, 2883-2892. [CrossRef]

40. Yu, Y.; Wei, W.; Chen, L.D.; Jia, F.Y.; Yang, L.; Zhang, H.D.; Feng, T.J. Responses of vertical soil moisture to rainfall pulses and land uses in a typical loess hilly area, China. Solid Earth 2015, 6, 595-608. [CrossRef]

41. Suleiman, A.A.; Ritchie, J.T. Modeling Soil Water Redistribution during Second-Stage Evaporation. Soil Sci. Soc. Am. J. 2003, 67, 377-386. [CrossRef]

42. Zhang, Q.; Shao, M.A.; Jia, X.; Zhang, C. Understory vegetation and drought effects on soil aggregate stability and aggregate-associated carbon on the Loess Plateau in China. Soil Sci. Soc. Am. J. 2018, 82, 106-114. [CrossRef]

43. Heberling, J.M.; McDonough MacKenzie, C.; Fridley, J.D.; Kalisz, S.; Primack, R.B. Phenological mismatch with trees reduces wildflower carbon budgets. Ecol. Lett. 2019, 22, 616-623. [CrossRef]

44. Moreno-Gutiérrez, C.; Battipaglia, G.; Cherubini, P.; Delgado Huertas, A.; Querejeta, J.I. Pine afforestation decreases the long-term performance of understorey shrubs in a semi-arid Mediterranean ecosystem: A stable isotope approach. Funct. Ecol. 2015, 29, 15-25. [CrossRef]

45. Jia, Y.-H.; Shao, M.-A. Dynamics of deep soil moisture in response to vegetational restoration on the Loess Plateau of China. J. Hydrol. 2014, 519, 523-531. [CrossRef]

46. Li, Y. Effects of forest on water circle on the Loess Plateau. J. Nat. Resour. 2001, 16, 427-432. (In Chinese)

47. Yang, L.; Chen, L.; Wei, W.; Yu, Y.; Zhang, H. Comparison of deep soil moisture in two re-vegetation watersheds in semi-arid regions. J. Hydrol. 2014, 513, 314-321. [CrossRef]

48. Han, X.; Gao, G.; Chang, R.; Li, Z.; Ma, Y.; Wang, S.; Wang, C.; Lü, Y.; Fu, B. Changes in soil organic and inorganic carbon stocks in deep profiles following cropland abandonment along a precipitation gradient across the Loess Plateau of China. Agric. Ecosyst. Environ. 2018, 258, 1-13. [CrossRef] 
49. Wang, C.; Wang, S.; Fu, B.; Li, Z.; Wu, X.; Tang, Q. Precipitation gradient determines the tradeoff between soil moisture and soil organic carbon, total nitrogen, and species richness in the Loess Plateau, China. Sci. Total Environ. 2017, 575, 1538-1545. [CrossRef]

50. Li, Y.Y.; Shao, M.A. Change of soil physical properties under long-term natural vegetation restoration in the Loess Plateau of China. J. Arid Environ. 2006, 64, 77-96. [CrossRef]

51. Marín, F.; Dahik, C.; Mosquera, G.; Feyen, J.; Cisneros, P.; Crespo, P. Changes in soil hydro-physical properties and SOM due to Pine afforestation and grazing in Andean environments cannot be generalized. Forests 2019, 10, 17. [CrossRef]

52. Tuo, D.; Gao, G.; Chang, R.; Li, Z.; Ma, Y.; Wang, S.; Wang, C.; Fu, B. Effects of revegetation and precipitation gradient on soil carbon and nitrogen variations in deep profiles on the Loess Plateau of China. Sci. Total Environ. 2018, 626, 399-411. [CrossRef]

53. McVicar, T.R.; Van Niel, T.G.; Li, L.; Wen, Z.; Yang, Q.; Li, R.; Jiao, F. Parsimoniously modelling perennial vegetation suitability and identifying priority areas to support China's re-vegetation program in the Loess Plateau: Matching model complexity to data availability. For. Ecol. Manag. 2010, 259, 1277-1290. [CrossRef]

54. Lu, N.; Fu, B.; Jin, T.; Chang, R. Trade-off analyses of multiple ecosystem services by plantations along a precipitation gradient across Loess Plateau landscapes. Landsc. Ecol. 2014, 29, 1697-1708. [CrossRef]

55. Yu, Z.; Liu, S.; Wang, J.; Wei, X.; Schuler, J.; Sun, P.; Harper, R.; Zegre, N. Natural forests exhibit higher carbon sequestration and lower water consumption than planted forests in China. Glob. Chang. Biol. 2019, 25, 68-77. [CrossRef]

56. Cao, S.; Sun, G.; Zhang, Z.; Chen, L.; Feng, Q.; Fu, B.; McNulty, S.; Shankman, D.; Tang, J.; Wang, Y.; et al. Greening China naturally. Ambio 2011, 40, 828-831. [CrossRef]

(C) 2019 by the authors. Licensee MDPI, Basel, Switzerland. This article is an open access article distributed under the terms and conditions of the Creative Commons Attribution (CC BY) license (http://creativecommons.org/licenses/by/4.0/). 